Politik Indonesia: Indonesian Political Science Review 1 (1) (2016) 69-86

Politik Indonesia

Indonesian Political Science Review

http://journal.unnes.ac.id/nju/index.php/JPI

\title{
Mengkaji Ruang Publik dari Perspektif Kuasa: Fenomena Kemenangan Aktor Hegemonik Melalui Dominasi Budaya
}

\author{
Erisandi Arditama ${ }^{1 凶}$ \\ ${ }^{1}$ Universits Negeri Semarang, Indonesia
}

\section{Info Artikel}

Sejarah Artikel:

Diterima 31 Oktober 2015

Disetujui 15 Desember 2015

Dipublikasi 15 Januari 2016

\section{Keywords:}

Public Sphere; Gardu;

Hegemony

\section{Abstrak}

Ruang publik di tingkat lokal bukanlah ruang terbuka tanpa kuasa, melainkan ruang bertemunya beragam aktor dengan ragam kepentingan yang berbeda. Oleh sebab itu, dengan mengkaji aktivitas meronda di dalam gardu, artikel ini mendiskusikan tentang bagaimana kuasa bekerja di dalam ruang publik. Gagasan Gramsci tentang hegemoni digunakan untuk menganalisa relasi kuasa yang terjadi. Sebagai penutup, artikel ini menegaskan bahwa, upaya mempengaruhi opini publik melalui dominasi budaya, menjadi basis kemenangan aktor hegemonik dalam memenangkan pengaruh di dalam gardu sebagai ruang publik.

\section{Abstract}

Public sphere is not an open space without power, but intersection of various actors with their interest. Therefore, by taking study on meronda activity in gardu, this article discusses how power works in public sphere. Gramsci notion on hegemony is used to analyze existing power relation. As closing session, this article claims that efforts to affecting public opinion through culture domination becomes the basis of hegemonic actor victory in influencing power in gardu as pubic sphere.

(C) 2016 Universitas Negeri Semarang

\footnotetext{
$\triangle$ Alamat korespondensi:

Universits Negeri Semarang, Kampus Sekaran, Gunung Pati, Semarang Jawa Tengah 50229, Indonesia

Email: arditama.sandy@gmail.com
}

ISSN 2477 - 8060 


\section{Pendahuluan}

Tulisan ini akan mendiskusikan tentang bagaimana aktor hegemonik menanamkan pengaruhnya dalam membentuk opini publik di dalam ruang publik. Kajian ini penting dilakukan untuk memahami relasi kuasa yang terjadi di dalam ruang publik pada ranah lokal. Hal ini menarik, sebab, banyak kajian tentang ruang publik yang mengabaikan konteks kuasa. Ruang publik pun seringkali dibayangkan hanya sebagai ruang terbuka tanpa kuasa; yang sekedar mengasaskan adanya persamaan kedudukan, komunikasi yang simetris, serta tidak ada aktor dan kepentingan yang mendominasi.

Corak kajian ini tentu berbeda dengan kajian yang telah dilakukan oleh oleh Habermas. Bagi Habermas, ruang publik tidak dapat dilepaskan dari konteks kuasa. Di dalam karyanya yang menjelaskan kemunculan ruang publik borjuis di Eropa, Habermas juga sempat mengirimkan nada pesimisme yang cukup kuat mengenai masa depan ruang publik. Sebab, perkembangan ruang publik selama ini sangat dipengaruhi oleh kepentingan pengusa, terutama negara dan kekuatan modal (Habermas, 2010; Prasetyo, 2012).

Hardiman (2009) bahkan menulis, ruang publik yang dipengaruhi oleh kekuasaan tersebut, didominasi oleh aktor pemakai, suatu istilah baru yang dikenalkannya. Istilah itu merujuk pada aktor yang tidak lahir di dalam ruang publik, tetapi hadir, menduduki, dan ikut berpartisipasi di dalam ruang publik, dengan memanfaatkan uang dan pengaruhnya untuk memperalat publik. Aktor ini memiliki identitas sosial berupa legitimasi sosial yang kuat di dalam masyarakat (Prasetyo, 2012: 177).

Maka, jika dicermati secara mendalam, ruang publik bukanlah ruang terbuka tanpa kuasa yang bebas dari kepentingan. Ruang publik, dengan segala dinamika aktor di dalamnya, justru sebagai ruang tempat bertemunya multi aktor yang memiliki beragam kepentingan. Pada titik ini, ruang publik hadir secara politis. Ruang publik pun menjadi ruang kontestasi kuasa melalui ragam kepentingan multi aktor yang bertemu di dalamnya. Bertolak dari hal tersebut, untuk memahami relasi kuasa yang terjadi, kajian ini memfokuskan pada persoalan, bagaimana aktor-aktor di dalam ruang publik berelasi dengan kepentingannya yang berbeda. Untuk memudahkan upaya mencermati dinamika relasi kuasa yang ada, kajian ini menggunakan gardu sebagai titik kajian.

Pasca reformasi, gardu mengalami metamorfosa yang cukup menarik dengan sifatnya yang semakin terbuka dan dinamis. Sebelumnya, gardu digunakan sebagai salah satu instrumen keamanan lingkungan oleh rezim Orde Baru. Ia sekaligus menjadi instrumen negara dalam mengawasi perilaku maupun aktivitas warga negara. Aturan "Tamu wajib lapor" merupakan amunisi kontrol atas nama upaya untuk mengamankan lingkungan. Banyak petugas keamanan, 
termasuk penjaga gardu, direkrut dari warga sipil, namun dibekali pendidikan bercorak militer. Hansip (pertahanan sipil) adalah sebutan untuk penjaga gardu lengkap dengan seragam khas yang dikenakan. Mantan anggota TNI dan POLRI juga mendominasi segala hal yang berkaitan dengan isu keamanan lingkungan sekaligus memiliki legitimasi sosial untuk ikut meronda di dalam gardu.

Dengan adanya demokratisasi pasca reformasi, babak baru liberalisme politik, sosial, dan ekonomi terjadi. Sentralitas kekuasaan yang menjadi karakter Orde Baru pun tersebar, baik secara vertikal maupun secara horisontal. Penyebaran secara vertikal salah satunya ditandai dengan penyelenggaraan desentralisasi dan otonomi daerah secara luas. Sedangkan secara horisontal dapat dilihat dari beberapa hal, termasuk fenomena penguatan fungsi dan wewenang parlemen serta membatasi masa jabatan presiden. Di tingkat lokal, relasi antara kepala daerah dengan DPRD harus senantiasa sinergis dan koordinatif.

Saat Orde Baru berkuasa, simpul daya kontrol dan pengawasan negara atas kehidupan sosial dan politik warga negara begitu kuat dengan karakternya yang begitu represif (Anderson, 1990; Benda, 2010; King, 2010; McVey, 2010). Isu mengenai kebebasan berserikat dan berkumpul kian mengemuka sebagai ide dasar perjuangan mewujudkan demokratisasi. Pasca reformasi, daya kontrol negara yang kuat dan represif itupun terurai.
Ruang publik bermunculan seiring dengan menguatnya civil society. Obrolan-obrolan publik dapat dilakukan di mana saja. Termasuk di dalam gardu, sebagai efek dari runtuhnya sistem intelijen negara berbaju sipil. Hal ini sekaligus menandakan bahwa, masyarakat sipil memegang kendali atas politik ruang, di mana pada saat Orde Baru, gardu digunakan oleh negara sebagai bagian dari politik keamanan. Dengan menggunakan praktek militer, negara menggunakan gardu sebagai posko untuk mengawasi segenap aktivitas masyarakat (Kusno, 2007: 39-41).

Akan tetapi, kajian ruang publik yang ada selama ini seringkali masih mengabaikan konteks kuasa. Ruang publik masih diimajinasikan sebagai ruang berkumpul dan bertemunya beragam aktor. Relasi di dalamnya pun seringkali dipahami bersifat egaliter, tanpa memiliki penguasa, tanpa ada yang dikuasi, serta tidak ada kekuasaan represif yang memaksa. Namun, memahami ruang publik sebagai ruang terbuka dan mengabaikan konteks kuasa adalah sebuah kesesatan berpikir. Justru, ruang publik, termasuk dinamika di dalamnya, merupakan ruang yang sarat dengan kepentingan.

Pada kondisi demikian, ruang publik dilihat sebagai arena kontestasi kuasa antar aktor yang ada. Kontestasi tersebut didasari oleh adanya kepentingan aktor yang berbedabeda. Kontestasi yang ada merupakan proses mempengaruhi opini publik secara halus di dalam ruang publik itu sendiri. Menelisik bagaimana kontestasi kuasa terjadi di dalam 
ruang publik agar dapat memahaminya secara mendalam begitu penting di masa perkembangan politik nasional yang telah menyediakan pelbagai ruang publik yang begitu terbuka. Untuk membatasi cakupan pembahasan, kajian ini mengamati salah satu gardu yang ada di Sleman, yakni gardu di RW 02 Karangwuni Tengah, Sleman, dengan satu pertanyaan mendasar: bagaimana terjadinya kontestasi kuasa di dalam gardu sebagai ruang publik?

\section{Kajian Pustaka}

\section{Sejarah Kelahiran Ruang Publik}

Kajian tentang ruang publik bukanlah hal baru. Ruang publik telah banyak dikaji sebelumnya. Namun, kajian yang ada memiliki argumentasi yang cenderung sama, yakni, ruang publik merupakan bagian yang sangat penting bagi upaya penguatan demokrasi dan kekuatan masayarakat sipil yang otonom yang akan memperkuat ruang publik itu sendiri (Arendt, 1958; Fraser, 1992; Keane, 2000; Putnam, 2001; Taylor, 2002; dan Prasetyo, 2012).

Gagasan ruang publik secara teoritis dirintis oleh Habermas melalui kajiannya tatkala meneliti munculnya ruang-ruang diskusi di kafe-kafe Eropa pada abad pertengahan. Habermas ingin menjelaskan; munculnya ruang publik tidak dapat dilepaskan dari persoalan relasi kuasa yang dibangun oleh kaum borjuis. Tekanan politik dari media berupa surat kabar dan berkembangnya kapitalisme pada abad ke 18 , turut membentuk pengaruh kelas terdidik kaya untuk mendominasi perdebatan-perdebatan kritis atas suatu masalah sosial secara luas di dalam ruang publik.

Di sisi lain, munculnya ruang publik di Eropa juga disebabkan adanya penghilangan otoritas berbasis tanah yang dimiliki oleh penguasa teritorial. Sistem feodal runtuh, digantikan oleh kuasa kapital. Kondisi ini melahirkan ruang terjadinya relasi kuasa yang baru dan berbeda, yang dikenal sebagai ruang publik borjuis, yang dalam pengertian modern sebagai ruang otoritas publik (Habermas, 2010). Ruang publik pun memainkan fungsi sentralnya secara politis: menjadi ruang terbuka di antara publik dan negara (state) yang dapat digunakan untuk mendiskusikan segala sesuatu yang berkaitan dengan publik. Sehingga, ruang ini dapat digunakan untuk mendebat negara atas isu-isu publik atau isu privat yang memiliki relevansi dengan masalah publik seperti isu pertukaran sosial dan dan komoditas (Habermas, 1989; Prasetyo, 2012).

Kaum borjuis saat itu juga memiliki pengaruh yang cukup kuat dalam mempengaruhi ruang publik. Kapasitas untuk mempengaruhi ruang publik disebabkan adanya sumber daya yang dimiliki oleh para borjuis, baik berupa modal, intelektual, maupun jejaring bisnis. Untuk mendukung informasi agar dapat memperkuat bisnis, industri surat kabar berkembang pesat. Perkembangan surat kabar juga turut 
berpengaruh pada pembentukan opini publik dan menjadi bahan diskusi sehari-hari.

Di titik ini, opini publik yang terbentuk melalui diskusi-diskusi pada perkembangannya dapat mempengaruhi dan memiliki daya paksa bagi otoritas negara untuk melakukan apa yang diinginkan oleh publik. Ruang publik hadir lagi dalam rupa yang berbeda; ia hadir secara politis, ketika masyarakat sipil (kaum borjuis) mulai melancarkan gugatan terhadap klaim kepublikan segala kebijakan yang dibuat oleh negara dan melayani kepentingan publik (Prasetyo, 2012).

Pada masa awal berkembangnya kapitalisme, kaum borjuis diisi oleh para kapitalis maupun saudagar-pengrajin. Pada perkembangan selanjutnya, kaum borjuis juga meliputi kaum cendekiawan terdidik yang sekaligus membentuk kelas baru, yaitu kelas terdidik (educated class) yang memiliki peran sentral karena menguasai jabatan-jabatan publik. Kelas ini diisi oleh para hakim, dokter, pastor, scholar, dan jabatan terdidik lainnya atau yang disebut Habermas sebagai publik yang terbiasa membaca. Selain itu, para bankir, saudagar, penguasaha, dan pemilik pabrik yang membuka relasi dengan negara juga berupaya masuk dan menjadi bagian kelas borjuis baru tersebut.

Pergeseran struktur sosial ini menyebabkan terbentuknya ruang publik masyarakat sipil yang tidak bergantung pada otoritas-otoritas yang ada. Ruang publik masyarakat sipil ini mengukuhkan eksistensinya sebagai tempat di mana masyarakat privat yang sebelumnya berkumpul bersama-sama untuk membentuk sebuah publik. Maka ruang publik borjuis tidak lain merupakan ruang masyarakat privat yang berkumpul bersama menjadi sebuah publik (Ibid: 41). Ruang publik borjuis pada perkembangannya pun tidak dapat dilepaskan dari pengaruh dan kepentingan kaum borjuis.

Embrio ruang publik borjuis saat itu terjadi sekitar tahun 1670-an. Kedai-kedai kopi di Inggris Raya dan salon-salon di Perancis telah menjadi ruang di mana orangorang sering mendiskusikan kegelisahan politiknya. Kristalisasi kegelisahan politik tersebut mencapai puncaknya, tatkala mampu mendesak pemerintah Inggris Raya bersikap atas suatu masalah. Obrolan-obrolan di kedaikedai kopi merupakan pesan kebebasan untuk mendebat kebijakan negara, membahas dan membantah klaim keberhasilan negara, membahas kejahatan, masalah sosial, dan sebagainya (Ibid: 86).

\section{Kajian Kuasa di Dalam Ruang Publik}

Di dalam perspektif politik, ruang publik tidaklah bebas dari konteks kuasa. Ruang publik pada hakikatnya merupakan ruang bertemunya multi aktor yang memiliki beragam kepentingan. Memahami ruang publik dari konteks kuasa merupakan sesuatu yang penting di dalam kajian ilmu politik. Sebab, dengan mengkaji dinamika kontestasi kuasa yang ada, upaya memahami bagaimana kekuasaan ditanamkan, dikelola, dan 
dipertahankan di dalam ruang publik dapat dijelaskan secara mendalam.

Selain itu, kajian ruang publik dari perspektif kuasa memiliki beragam makna. Lofland (2007) dalam Prasetyo (2010) menjelaskan, betapa ruang publik memiliki pengertian yang berbeda, digunakan secara tidak ketat, serta tergantung pada konteks ilmu yang mengkajinya. Maka, memahami ruang publik sebagai sesuatu yang bersifat teknis-arsitektural berupa taman dan ruang terbuka hijau, merupakan bagian dari ilmu tata kota (planologi) dan arsitektur; cyberspace sebagai tempat berinteraksi di dunia maya merupakan kajian dunia digital; dan bagi aktivis feminisme, ruang publik adalah arena sosial tempat segala hal yang mengeksklusi perempuan disusun. Priyono (2010) juga menulis, salah satu pengertian ruang publik adalah tempat publik, yaitu, ruang yang dapat digunakan untuk saling berdiskusi atau berdebat (Prasetyo, 2012: 170).

Dengan adanya ragam makna yang berbeda dari para pengkaji ruang publik, baik dari sisi politik maupun perspektif yang lain, ternyata kajian ruang publik masih menyisakan limitasi kajian dalam menjelaskan bagaimana kuasa bekerja di dalam ruang publik. Cara bekerjanya kuasa dari para pemilik kuasa begitu penting untuk dipahami. Sebab, dengan demikian, kajian ruang publik dari sisi politik diharapkan tidak lagi bersifat abstrak, melainkan dapat dikaji hingga pada persoalan bagaimana para aktor yang memiliki kuasa dapat menanamkan kuasanya di dalam ruang publik. Kuasa tersebut, baik berupa pengaruh, daya paksa, maupun daya kontrol, akan memiliki pengaruh terhadap pembentukan opini publik dan penerimaan publik atas suatu isu bersama.

Yang menarik adalah, ketika Yasraf A. Piliang (2004) berpendapat, kajian mengenai ruang publik banyak yang mengabaikan konteks kuasa. Melalui tulisannya, ia mengawali kajian teoritik untuk mendudukkan gejala-gejala yang terjadi pada ruang publik. Secara implisit ditekankan bahwa, kuasa yang bekerja di dalam ruang publik yang sarat kepentingan, seringkali tidak mendapat perhatian dari pemikir dan ilmuwan sosial. Padahal baginya, ruang publik tidak dapat dilepaskan dari pertarungan kuasa dan ideologi. Kelompok yang dominan dan mendominasi itulah yang mampu keluar sebagai "pemenang". Opini publik sebagai ekspresi penerimaan publik tidak lain merupakan hasil dari bekerjanya kekuasaan yang mendominasi tersebut.

Lalu, bagaimana kuasa itu bekerja? Piliang menjelaskan, jika ruang publik tidak dapat dilepaskan dari pertarungan kuasa dan ideologi, maka konsep hegemoni merupakan kata kunci untuk menjelaskan bekerjanya kekuasaan di dalam ruang publik. Baginya, konsep hegemoni yang dijelaskan Gramsci terjadi tatkala kekuasaan yang ada mampu menggiring penerimaan publik terhadap suatu gagasan. Sebab, hegemoni didefinisikan sebagai ketidakmampuan orang-orang yang 
memiliki keyakinan tertentu untuk yakin dengan keyakinannya untuk berbeda (Jones, 2009: 1010). Penerimaan publik pada akhirnya, diekspresikan melalui mekanisme opini publik. Oleh sebab itu, ruang publik memiliki peran sentral dalam membentuk opini publik. Hal ini untuk memastikan praktek hegemoni berlangsung secara terus menerus sebagai ekspresi bekerjanya kekuasaan yang ada.

Sistem nilai yang dimiliki oleh suatu masyarakat nantinya, pada akhirnya merupakan hasil dari pertarungan hegemonik itu sendiri. Di titik ini, aktor-aktor kepentingan yang ada bukan hanya berkepentingan dakam rangka mengkomunikasikan gagasan di dalam ruang publik. Lebih jauh, aktor-aktor yang berkepentingan tersebut menjadi bagian dalam relasi saling mempengaruhi satu sama lain secara kompleks melalui model yang dikatakan Gramsci sebagai pertarungan hegemonik yang didominasi oleh keunggulan kultural (Ibid: 10).

Jika ruang publik dimonopoli oleh kelompok kultural, Piliang menegaskan, ruang publik tersebut berpotensi terjadi apa yang disebut Bourdieu sebagai kekerasan simbol. fenomena ini terjadi jika sebuah "bentuk kekerasan yang halus dan tak tampak", yang di baliknya menyembunyikan beragam pemaksaan dominasi, termasuk dominasi bahasa, tanda, dan pemaknaan. Kekerasan simbol bukan saja terjadi melalui bentuk dominasi media komunikasi, melainkan juga penggunaaan dominasi media komunikasi sedemikian rupa di dalam ruang publik.

Implikasi dari adanya kekerasan simbolik di dalam ruang publik adalah adanya penyimpangan dari dunia realitas yang sesungguhnya, akibat relasi komunikasi yang ada, dimanipulasi oleh pemilik kuasa. Ruang publik yang ada justru dimanipulasi untuk melanggengkan kekuasaan kelompok dominan dengan cara mendominasi media komunikasi, bahasa, tanda, serta interpretasi terhadapnya. Ketika publik menerima dan memberi pengakuan atas simbol-simbol yang telah terdistorsi tersebut, hal ini menjelaskan bagaimana kekuasaan telah bekerja dan berhasil melakukan suatu kekerasan simbolik dengan cara yang halus (Ibid: 12). Di titik inilah proses hegemonik telah berlangsung, tatkala kekerasan simbolik yang dilakukan dengan cara yang halus dapat merasuki alam bawah sadar kesadaran publik.

Dalam perkembangan selanjutnya, banyak ilmuwan sosial yang melakukan kajian tentang ruang publik dalam konteks kekuasaan secara lebih spesifik. Ruang publik dibayangkan sebagai ruang tempat bertemunya beragam kepentingan. Kontestasi kepentingan ini tidak dapat dilepaskan dari posisi ruang publik yang berada di antara negara (state) dan aktor lainnya. Oleh sebab itu, kajian kekuasaan sungguh tidaklah dapat dipisahkan dari kajian tentang kekuasaan.

Jika Habermas melihat ruang publik sebagai sesuatu yang ideal, di mana segala kepentingan yang bersitegang dapat 
dibicarakan di ruang publik, untuk mencapai suatu konsensus bersama melalui tindakan komunikatif, pada prakteknya tidaklah demikian. Tindakan komunikatif yang dimimpikan Habermas adalah sarana untuk merekonstruksi prasyarat umum bagi komunikasi bebas penguasaan, yaitu komunikasi yang genuine: tidak terdistorsi secara ideologis (Hardiman, 2009: 219). Kajian Habermas tentang ruang publik dikembangkan dalam kultur Eropa di mana kaum borjuis yang memiliki budaya santun para aristokrat telah mempengaruhi ruang publik untuk motif ekonominya. Lalu, bagaimanakah ruang publik dalam konteks Indonesia yang memiliki beragam konteks budaya lokal, tatkala ruang publik digunakan oleh kekuatan dominan lokal untuk kepentingannya?

Pemikiran-pemikiran Habermas yang terjalin dalam gagasannya tentang ruang publik, teori-teori komunikasi dan tindakan komunikatif, maupun gagasannya tentang demokrasi deliberatif merupakan sesuatu yang abstrak. Kelanjutan kajian mengenai kata kunci-kata kunci yang pernah dikenalkan olehnya mendesak untuk terus diperbaharui dan dilakukan pengembangan pemikiran Habermas. Hal ini penting untuk mengkontekstualisasikan pemikiran Habermas pada konteks kekinian dalam perkembangan kajian politik lokal.

Nusantara memiliki ragam budaya yang begitu kompleks, sehingga benturan kepentingan sulit untuk dihindarkan. Dalam konteks ruang publik, kaum borjuis pun bukanlah satu-satunya kelompok yang mempengaruhi ruang publik. Kekuatan figuritas dengan modal sosio-kultural yang kuat juga memiliki peran sentral dalam mempengaruhi opini publik di dalam ruang publik. Ikatan primordial begitu kental dalam ragam budaya lokal. Maka, argumentasi lain yang hendak dibangun melalui tulisan ini adalah; terdapat aktor lain yang bukan bagian dari kaum borjuis, juga dapat mempengaruhi ruang publik di tingkat lokal.

\section{Melacak Metamorfosa Gardu dari Sisi Sosio- Historis}

Abidin Kusno menulis mengenai gardu untuk melengkapi kajian tentang ruang publik. Walaupun kajiannya tentang gardu berawal dari semangat memahami makna fisik gardu akibat adanya metamorfosis di dalam gardu itu sendiri, bagi Kusno, gardu memiliki memori dan jejak makna yang khas. Secara fisik, gardu merupakan bangunan yang mudah ditemukan di sekitar lingkungan tempat tinggal. Dia melacak sejarah bagimana gardu itu muncul. Penelusuran sejarah dilakukan hingga Kusno menarik kesimpulan bahwa gardu muncul sebagai representasi negara kolonial di Jawa pada abad ke 19 untuk mereorganisasi ruang kota dan desa. Pada periode yang sama, gardu juga digunakan sebagai bentuk pertahanan bagi etnis Tionghoa yang hidup pada masa kekacauan, saat kekerasan diarahkan kepada mereka (Kusno, 2007: 43). 
Secara sosio-historis, gardu tampil sebagai sebuah institusi negara dan lingkungan tertentu, sedangkan di sisi yang lain gardu tampil sebaagai tempat melakukan perlawanan. Hal ini menegaskan bahwa sejarah gardu tidak dapat dilepaskan dari konteks politik ruang di zaman kolonial, termasuk jalan raya tingkat propinsi, konstruksi politik "komunitas desa", pembentukan polisi kota di Jawa pada awal abad ke 20, dan pengalaman-pengalaman kelam masyarakat Tionghoa pada masa itu.

Kusno juga menuliskan betapa gardu tidak dapat dipisahkan dari konteks kuasa. Di saat pengaruh feodalisme masih kuat, sebenarnya gardu telah ada di Jawa sebelum kedatangan kolonial. Gardu bisa dijumpai di pintu masuk kediaman bangsawan atau orangorang terkemuka. Tetapi, keberadaan gardu pada saat pra kolonialisme bukan untuk menegaskan politik ruang (batas teritori maupun untuk pertahanan dan perlawanan), melainkan sebagai simbol filosofis Jawa untuk menunjukkan kuasa raja sebagai pusat kosmos.

Fungsi gardu sebagai fungsi teoritorial (batas wilayah) mulai dilakukan pada saat pemerintahan Gubernur Jenderal Herman Willem Daendels. Pada masa pemerintahannya, gardu digunakan sebagai institusi keamanan dengan menjalankan fungsi ronda siang dan malam. Setelah melembagakan ide tentang batas wilayah dengan membagi daerah ke dalam ruangruang politik yang disebut karesidenan,
Daendels menghubungkan wilayah-wilayah karesidenan tersebut dengan sebuah jalan raya atau Jalan Pos Besar yang membentang dari pantai barat Anyer sampai pantai timur Banyuwangi. Di jalan ini juga dibangun serangkaian pos-pos sebagai gardu jaga untuk para musafir yang butuh mengganti kudakuda mereka. Di dalam gardu-gardu inilah ronda rutin mulai dilakukan untuk stabilitas dan keamanan lingkungan kampung maupun perkebunan di sekitar gardu atau postweg.

Dengan berpijak pada konsep politik ruang yang memiliki batas-batas wilayah, gardu memiliki peran yang cukup sentral. Ia menjadi penanda batas, institusi keamanan, sekaligus penghubung antar wilayah. Pembentukan komunitas pedesaan dengan menjadikan gardu sebagai pintu masuk utama, sekaligus membentuk konstruksi identitas pedesaan dan perkotaan. Atas dasar itulah, tatkala pembentukan polisi Jawa, pos polisi menggunakan model gardu untuk menunjukkan simbol kuasa, fungsi keamanan, dan batas wilayah.

Pada saat Orde Baru berkuasa, fungsi gardu sebagai basis keamanan diberi fungsi yang maksimal. Negara menggunakan gardu sebagai mata telinga dalam mengontrol dan mengawasi aktivitas masyarakat. Gardu dijadikan sebagai pos keamanan lingkungan (poskamling) ataupun siskamling (sistem keamanan lingkungan). Kelompok semi militer yang memiliki kultur militeristik menjadi penjaga keamanan lingkungan dengan sebutan hansip (pertahanan sipil). 
Pengawasan dan pembatasan jumlah RT-RW dilakukan, mengadakan aturan tamu harap lapor, dan sebagainya. Sehingga pada titik ini, gardu telah menjadi bagian dari politik negara.

Keruntuhan rezim orde Baru menyebabkan jaringan negara yang terbangun melalui pos hansip menjadi hancur, namun struktur fisiknya masih tegak berdiri dan fungsinya pun mengalami transformasi. Para individu dan komunitas menggunakannya untuk menjaga diri, keluarga, serta harta bendanya (Ibid). Rezim keamanan pasca reformasi pun berubah yang ditandai dengan fenomena masyarakat sipil sebagai aktor penting dalam mewujudkan keamanan lingkungannya. Gardu pun digunakan oleh warga secara kolektif. Sehingga pada perkembangannya, ia tidak hanya digunakan untuk menjaga keamanan kampung saja, melainkan juga sebagai tempat untuk bertemu maupun berdiskusi.

Oleh sebab itu, pembangunan gardu pada masa reformasi tidak melalui campur tangan negara lagi. Urusan dan aktivitas keamanan lingkungan menjadi urusan masyarakat sipil, sekaligus aktivitas-aktivitas komunikasi di dalamnya. Sehingga, pada perkembangan, gardu-gardu yang ada menjadi sebuah ruang publik baru untuk membangun daya komunikasi antar warga secara bebas; tanpa dominasi kekuatan negara yang represif.

\section{Dari Gardu Menuju Balai RW}

Jika kita menyeksamai, obrolan sesama peronda di dalam gardu cukup menarik. ${ }^{33}$ Meronda sambil menonton televisi, mengobrol, dan bermain kartu merupakan aktivitas peronda saat melakukan ronda malam. Televisi yang ada, diletakkan di tengah-tengah ruangan di dalam gardu. Letak televisi ditempatkan dengan posisi sedikit lebih tinggi dari lantai tempat para peronda mengobrol sambil bermain kartu dan menonton televisi. Topik obrolan bisa meliputi keadaan lingkungan sekitar, sampai dengan topik nasional yang diberitakan siaran TV.

Dari pengamatan dan keterlibatan langsung terhadap akvitas ronda, permainan kartu, menonton televisi, mengobrol banyak hal, merupakan penyebab utama terwujudnya suasana yang cair, nyaman, dan akrab selama meronda. Adanya kesempatan yang sama bagi semua warga (topik obrolan, permainan, dan akses menonton televisi) membuat sesama peronda merasa diwongke (diorangkan). Suasana guyup dan rukun nampak begitu jelas. Konsumsi bagi peronda disediakan oleh warga secara bergiliran sesuai jadwal yang ada. Kadang-kadang ada suguhan polo

33 Data lapangan disimpulkan melalui pengamatan selama 7 hari, yakni pada tanggal 7 Januari sampai dengan 14 Januari 2013 di salah satu gardu di Karangwuni Tengah. Esoknya, tanggal 18 Januari 2013, penulis mengikuti salah satu rapat warga di Balai RW 02 di Karangwuni. Penulis juga ikut meronda pada malam harinya, sekaligus mencermati perilaku para peronda. Kadangkala, penulis juga ikut berkeliling dan bermain kartu untuk memahami secara lebih mendalam, bagaimana interaksi antar aktor serta relasi kuasa yang terjadi dalam gardu. 
mendem berupa kacang rebus dan pisang rebus. Minuman yang ada dan selalu ada: kopi hitam.

Menariknya, kesepakatan bersama dalam menjalankan aktivitas kampung, dibicarakan di dalam gardu saat meronda. Berdasarkan kesepakatan bersama, aktivitas ronda dibagi-bagi menjadi berkelompokkelompok. Ada delapan kelompok yang bertugas ronda dengan masing-masing kelompok satu koordinator kelompok ronda. Aktivitas ronda dilakukan setiap hari secara bergiliran sesuai dengan kelompoknya masing-masing. Setiap kelompok berjumlah sekitar tujuh sampai delapan orang. Pengaturan anggota ronda dibicarakan dan dibahas di rapat RW setiap empat puluh hari sekali di balai RW. Hal ini merupakan kesepakatan bersama antar warga.

Setiap malam, peronda berkeliling kampung sekaligus mengambil uang sumpitan yang ada di kotak pagar di setiap pintu pagar rumah warga. Setelah selesai meronda, para peronda kembali ke gardu. Aktivitas rutin yang dilakukan di dalam gardu: menghitung uang sumpitan yang didapat dan membagi rata antar anggota kelompok (ada juga yang ditabung kemudian dibagikan berdasarkan kesepakatan, misalkan menjelang lebaran), berdiskusi, menonton televisi, dan bermain kartu sampai menjelang shubuh.

Topik yang diobrolkan di dalam gardu bermacam-macam, terutama mengenai keadaan yang ada di lingkungan terdekat untuk mendukung kebersamaan warga.
Misalnya, mengenai rencana peringatan tujuh belasan berupa tirakatan warga, senam bersama ibu-ibu, dan nonton bareng laga sepakbola pertandingan tim nasional. Dari obrolan-obrolan yang ada, berkembang menjadi topik bersama dan menyebar sampai kepada kelompok ronda yang lain. Fenomena ini dapat terjadi, sebab, ada beberapa anggota kelompok ronda yang terkadang ikut berkumpul dengan kelompok ronda yang lain, walaupun bukan jadwalnya dan anggota kelompoknya dalam meronda. Usulan yang diawali dengan obrolan yang cair dan akrab tersebut, pada realitanya, mudah untuk menjadi kesepakatan bersama atas isu yang baru saja berkembang.

Misalnya, untuk isu penutupan portal di atas pukul 00.00 WIB pada setiap malam. Isu ini cepat menyebar dan disetujui para peronda. Ketua RT yang sering ikut meronda lintas kelompok juga terlibat dalam obrolan warga di dalam gardu. Isu-isu tersebut menjadi usulan para peronda kemudian diinformasikan kepada kelompok ronda yang lain agar memperoleh pemahaman yang sama dan utuh mengenai isu penutupan portal di atas pukul 00.00 WIB di setiap malam. Setelah dibahas antar individu di dalam gardu dan antar kelompok peronda, pada akhirnya dapat diambil kesepakatan bersama: portal ditutup di atas pukul 00.00 WIB di setiap malam setiap harinya.

Pada saat rapat RW di Balai RW 02 berlangsung, kesepakatan-kesepakatan yang menjadi kesepakatan bersama para peronda 
disosialisasikan kepada warga secara luas. Warga yang ikut rapat RW dapat menambahkan usulan-usalannya. Aspirasi mereka ditampung oleh pengurus RW. Fenomena ini menjelaskan bahwa, usulan individu yang semula bersifat privat dapat berkembang menjadi isu bersama, dibicarakan secara bersama, untuk menghasilkan kesepakatan bersama, dimulai dari gardu sebagai bagian dari ruang publik.

Di sisi lain, rapat dan pertemuan warga di balai RW sekedar rutinitas dan sharing uneg-uneg warga. Forum tersebut juga menjadi ruang untuk menyambung silaturrahmi warga secara luas. Hal-hal yang dibicarakan biasanya tidak jauh berbeda dengan apa yang seringkali menjadi obrolan di dalam gardu. Misalnya, pola pembagian anggota ronda yang dianggap sering tidak hadir, jadwal ronda yang terkadang berbenturan dengan pekerjaan, pola pembagian hasil sumpitan ronda, serta kegiatan-kegiatan RW yang membutuhkan keterlibatan warga secara lebih luas. Contoh kasus yang umum meliputi kegiatan bersihbersih kampung bersama, membuat polisi tidur di jalan kampung, tirakatan kemerdekaan, senam bersama, nonton bareng sepak bola, dan sebagainya. Menariknya, isuisu tersebut merupakan topik obrolan utama yang sering dibahas dan didiskusikan di antara para peronda saat meronda.

Salah satu informan menjelaskan, kegiatan senam bersama dan nonton bareng sepak bola seperti pertandingan final timnas, diusulkan oleh beberapa peronda pada saat meronda. Agar kegiatan tersebut berjalan lancar, beberapa peronda mengusulkan agar jalan umum yang membentang di depan gardu ditutup. Usul ini pada awalnya disampaikan oleh seorang warga senior atau tokoh yang dituakan. Hal ini penting bagi banyak peronda, sebab, dengan menutup akses jalan dari pertigaan utara sampai pertigaan selatan di wilayah RW 02 Karangwuni Tengah, kegiatan senam bersama dan nonton bareng dapat dilangsungkan dengan lancar.

Warga juga diharapkan dapat berpartisipasi dan mengikuti acara bersama tersebut dengan nyaman. Maka, pada pertemuan RW, rencana senam bersama dan nonton bareng sekaligus isu mengenai rencana penutupan akses jalan dibahas dengan melibatkan warga secara lebih luas. Walaupun pada hakikatnya, sebagian besar peserta pertemuan RW adalah warga yang aktif meronda. Akhirnya, kesepakatan bersama diambil: jalan di depan gardu ditutup dengan menggunakan portal pada saat acara berlangsung. Pelajaran penting yang dapat disimpulkan dari fenomena ini adalah, legitimasi untuk mengatur buka-tutup portal pada awalnya, didapatkan melalui kesepakatan bersama yang diawali di dalam obrolan di dalam gardu itu sendiri.

Menanamkan Kuasa Melalui Dominasi Budaya

Jika dicermati secara lebih mendalam, obrolan yang terjadi di dalam gardu tidak 
dapat dipisahkan dari konteks kuasa. Obrolan di dalamnya secara umum terlihat begitu cair, egaliter, dan akrab. Namun, di balik itu semua, ada struktur kuasa yang tidak setara di antara para peronda. Struktur kuasa ini merupakan dasar terbentuknya relasi kuasa yang turut mempengaruhi pembentukan opini publik hingga nantinya menghasilkan kesepakatan bersama.

Di dalam konteks kajian ini, kuasa tersebut dimiliki oleh orang-orang yang dianggap tua atau dituakan. Sebab, warga yang sering meronda didominasi oleh orangorang yang dituakan, yaitu para senior kampung yang merupakan warga asli; dilahirkan, dibesarkan, telah puluhan tahun tinggal di Padukuhan Karangwuni. Para senior kampung ini pun juga dianggap begitu memahami adat istiadat yang ada yang telah diwariskan secara turun-temurun.

Selama pengamatan dan keterlibatan langsung di dalam aktivitas ronda, penulis jarang melihat para pemuda kampung yang ikut meronda. Sebagian besar peronda adalah para kepala keluarga yang usianya masih separuh baya. Hanya beberapa orang yang telah berusia tua dan menjadi senior kampung. Mereka -para peronda- merupakan warga asli atau warga pendatang namun telah lama tinggal di padukuhan ini. Mereka begitu memahami sejarah, perkembangan, dan dinamika padukuhan Karangwuni dari masa ke masa; sebagai salah satu padukuhan yang terdapat banyak kost, kontrakan mahasiswa, dengan segala dinamika sosio-kulturalnya.
Sebab, lokasinya begitu dekat dengan UGM sebagai universitas tertua di negeri ini.

Konteks kuasa yang terjadi di dalam garu pada saat meronda terlihat dari praktek dominasi kultural yang terjadi secara halus, yakni, penggunaan bahasa yang digunakan di dalam obrolan dengan bahasa Jawa khas Jogja. Bahasa Jawa merupakan bahasa yang memilki struktur tingkatan di dalam kaidah bahasanya. Bahasa Jawa menghendaki sang penutur bahasa sadar diri terhadap posisinya dan terhadap lawan bicaranya. Jika yang menjadi lawan bicara adalah yang lebih muda atau dianggap sebaya, bahasa yang digunakan adalah bahasa ngoko, bukanlah bahasa kromo ingggil. Sebaliknya, jika yang menjadi lawan bicara adalah orang yang lebih tua atau yang dituakan, maka bahasa yang digunakan adalah kromo inggil.

Pada konteks kajian ini, walaupun dinamika obrolan yang ada terlihat cair, egaliter, dan terbuka, pada hakikatnya justru menjelaskan adanya relasi yang asimetris atau tidak setara. Bahasa Jawa kromo inggil digunakan untuk orang yang lebih tua atau dituakan disertai bahasa tubuh yang mengesankan kesopanan agar tidak dianggap lancang. Ekspresi kesopanan dipraktekkan dengan tidak mengeluarkan nada tinggi, bersuara keras, termasuk tidak mengeraskan suara pada saat menimpali, menambah, atau bahkan menyanggah pendapat orang yang lebih tua atau yang dituakan. Fenomena ini menjadi penjelas bahwa ada relasi kuasa yang tidak setara yang kelak akan turut 
mempengaruhi dinamikan relasi kuasa di dalam gardu.

Selain itu, mencermati sikap tokoh yang dituakan tersebut juga cukup menarik. Sang tokoh memakai cincin akik besar di jari manis tangan kanan dan jari manis tangan kiri, tidak banyak bicara, dan tidak banyak bercanda. Namun, ketika terjadi obrolan mengenai permasalahan lingkungan, tokoh ini mendominasi obrolan, wacana, dan menjadi rujukan permasalahan sosial dari sisi budaya bagi peronda yang lain. Tokoh tersebut dihormati bukan hanya disebabkan dari golongan tua dari sisi usia, melainkan juga dihormati karena adanya alasan kultural.

Kapasitasnya yang mengerti ritual, adat, sekaligus sering memimpin tirakatan, dianggap sebagai kelebihan secara sosiokultural. Kelebihan tersebut menandakan bahwa ia layak untuk dituakan, walaupun bukan termasuk kaum bangsawan maupun priyayi. Di dalam ragam kajian, keduanya (bangsawan dan priyayi) begitu berbeda, baik secara sosial, maupun dari sisi kultural. Kebangsawanan diturunkan secara askriptif, sedangkan priyayi didapatkan dari keahlian, jabatan, dan pendidikan (Koentjaraningrat 1975; Sutherland, 1983; Dwipayana, 2001; Soemardjan, 2009; Arditama, 2015).

Selain itu, ada juga tokoh lain yang dituakan. Sang tokoh memiliki kemiripan ciri dan penampilan dengan tokoh pertama, namun memiliki gaya komunikasi yang berbeda: sering mengawali obrolan tentang isu tertentu agar nantinya direspon secara bersahutan oleh yang lain. Tokoh yang dituakan ini lebih banyak menyimak dan tidak mendominasi obrolan yang berlangsung, sebab memberikan kesempatan bagi yang lain untuk menyampaikan pendapatnya.

Setelah wacana yang diawalinya tadi telah mengerucut maupun terurai menjadi lebih sederhana, tokoh tersebut kemudian berbicara di akhir untuk "menyimpulkan" hasil obrolan. Ia juga menyampaikan pendapatnya atas wacana tersebut dengan gaya "berceramah", sering menghubungkannya dari sisi sosio-kultual, dan selalu mengaitkan pengetahuannya dengan sejarah wilayah Karangwuni. Intonasinya pelan dan suaranya lembut. Gesture semacam ini mengesankan kewibawaan dan kedudukan sosialnya yang dituakan.

Sepintas, tidak ada relasi kuasa di dalam obrolan. Namun secara kultural, telah terjadi dominasi dengan cara yang sangat halus. Orang-orang yang lebih muda berhatihati dalam bersikap tatkala menghadapi para tokoh yang dituakan ini. Jikapun hendak menyanggah pendapat tokoh yang dituakan, peronda atau watga yang lebih muda berusaha agar tetap menggunakan bahasa kromo inggil, disampaikan dengan santun, dan berakhlak. Namun, pada akhirnya, tokoh yang dituakan tetaplah pemenang dalam upaya mempengaruhi wacana. Para tokoh yang dituakan ini juga sering ikut kumpul, mengobrol, dan meronda di dalam gardu dalam setiap malam, walaupun berbeda 
kelompok ronda. Dari titik ini, begitu tampak bagaimana praktek dominasi budaya dilakukan secara berulang-ulang agar selalu dapat menanamkan dan mempertahankan pengaruhnya di dalam ruang publik.

Ketika isu publik yang bergulir di dalam gardu mengemuka, isu tersebut kemudian dibawa ke dalam rapat warga di Balai RW setiap empat puluh hari sekali. Isu yang dibahas biasanya merupakan isu publik yang membutuhkan partisipasi warga secara luas. Aktor yang aktif menyampaikan dan mempertahankan pendapat adalah mereka yang sering berkumpul di gardu untuk meronda. Sehingga, secara substansi, keputusan yang diambil di dalam rapat warga cenderung memiliki kesamaan dengan aspirasi-aspirasi orang-orang yang meronda.

Ada beberapa catatan hasil pengamatan yang cukup menarik untuk dikaji. Pertama, dominasi kultural yang terjadi, dilakukan secara halus untuk menggiring opini publik melalui kuasa budaya. Reproduksi legitimasi kultural untuk memperkuat figuritas dilakukan secara terus menerus. Kedua, cara tokoh tua atau tokoh yang dituakan dalam menyampaikan pendapat diupayakan oleh mereka agar tidak berkesan mendominasi dan menggurui. Namun, semua yang hadir, baik itu peronda yang berusia lebih muda maupun warga lain yang hadir pada saat rapat warga di balai RW, seolah tunduk pada kharisma tradisional yang melekat pada figur yang dituakan tersebut. Ketiga, cara warga yang lebih muda dalam menyanggah pandangan tokoh yang dituakan, disampaikan dengan sopan. Namun, pandangan yang disepakati pada akhirnya tetaplah pandangan dari para tokoh yang dituakan ini. Atas beberapa kesimpulan wawancara yang dilakukan, alasan yang disampaikan warga begitu sederhana: tokoh yang dituakan dianggap lebih mengetahui yang terbaik untuk kebaikan warga.

Dengan fenomena sosio-kultural yang meniscayakan dominasi budaya terjadi, praktek hegemoni -meminjam konsep Gramsci- maupun praktek kekerasan simbolik -meminjam konsep Bourdieu- terus dilakukan, direproduksi, dan diperkuat secara berulang-ulang. Hasil dari kontestasi kuasa yang begitu halus ini dalam upaya memenangkan pengaruh atas warga, tidak lain adalah munculnya penggiringan opini yang berhubungan erat dengan penerimaan publik atas suatu isu maupun upaya mencari solusi untuk memecahkannya. Maka, kontestasi kuasa untuk menggiring opini publik tidak dilakukan melalui konfrontasi fisik, melainkan dilakukan dengan kekuasan yang bekerja secara halus dari para tokoh yang dituakan. Di titik inilah terjadinya hegemoni yang dilakukan melalui dominasi budaya.

\section{Kesimpulan}

Ruang publik bukanlah ruang terbuka yang selalu mengasaskan persamaan, keterbukaan, dan kedudukan yang setara di antara para aktor di dalamnya. Ruang publik juga bukanlah ruang yang senantiasa bebas 
dari kepentingan maupun ruang terbuka yang tanpa penguasa. Sebaliknya, ruang publik justru merupakan ruang tempat bertemunya beragam kepentingan. Kontestasi kuasa untuk memenangkan pengaruh dan penerimaan publik atas suatu isu di dalam ruang publik pun menjadi keniscayaan. Oleh sebab itu, kajian tentang ruang publik sebaiknya tidak lagi berfokus pada persoalan sejarah, definisi, maupun bentuk ruang publik, tetapi bergeser pada persoalan, bagaimana kontestasi kuasa terjadi di dalam ruang publik.

Kajian ini menemukan bahwa, kontestasi kuasa terjadi melalui praktek hegemoni dalam mempengaruhi dan membentuk opini publik di dalam gardu. Praktek hegemoni terjadi melalui dominasi budaya -yang bagi Bourdieu disebut sebagai kekerasan simbolik- dengan tujuan utama: menanamkan pengaruh untuk dapat menggiring wacana, memenangkan opini, dan mempengaruhi penerimaan publik atas suatu isu publik. Bekerjanya kuasa tersebut melalui hegemoni dan dominasi budaya yang dilakukan oleh orang-orang yang dituakan di dalam struktur budaya Jawa. Menariknya, perjuangan tokoh yang dituakan untuk selalu menanamkan dan mempertahankan pengaruh terjadi secara halus. Perjuangan ini tidak melalui konfrontasi secara fisik, melainkan dengan menggunakan kekerasan simbolik dan dominasi atas budaya. Di titik ini, para tokoh yang dituakan menjelma menjadi aktor hegemonik.
Praktek hegemoni diawali dari pembicaraan-pembicaraan yang bergulir di dalam gardu. Kemudian, isu tersebut dibicarakan secara lebih luas di dalam rapat warga di Balai RW. Pembicaraan isu di dalam rapat di Balai RW tidak lagi bersifat substantif, melainkan hanya membahas rencana operasional dengan melibatkan warga secara lebih luas. Hal ini terjadi, sebab, sebagian peserta rapat merupakan para peronda aktif yang telah membahasnya di dalam gardu, termasuk tokoh yang dituakan yang telah mengawal dan mengikuti isu tersebut sejak awal. Jika pembahasan di Balai RW terdapat perbedaan, tokoh yang dituakan diminta untuk menengahi dan memberikan pendapatnya. Sehingga, walaupun banyak usulan atau pandangan berbeda dari peserta rapat RW yang lain, pandangan tokoh yang dituakan tetap menjadi pegangan dalam pengambilan keputusan akhir para warga.

Dengan demikian, terdapat dua argumentasi yang penting untuk didiskusikan secara lebih lanjut. Pertama, kemenangan tokoh yang dituakan dalam mempengaruhi opini dan penerimaan publik atas suatu isu merupakan puncak dari perjuangannya hegemoniknya. Dominasi atas budaya yang dilakukannya selama ini pada akhirnya merupakan cara para aktor hegemonik agar tetap dapat memenangkan pengaruh dan melestarikan kuasanya. Kedua, pembahasan mengenai isu publik yang dibicarakan di dalam ruang publik dengan melibatkan publik secara luas, tidak harus untuk mendebat 
kebijakan negara saja, melainkan juga dapat digunakan untuk mewujudkan kepentingan publik dan kebaikan bersama secara mandiri dan otonom.

\section{Daftar Pustaka}

Arditama, E. (2013). Mereformasi Birokrasi dari Perspektif Sosio-Kultural: Inspirasi dari Kota Yogyakarta. Jurnal Ilmu Sosial dan Ilmu Politik, 17(1), 85-100.

Arendt, H. (2013). The human condition. University of Chicago Press.

Benda, H. J., \& Feith, H. (1964). Democracy in Indonesia.

Dwipayana, A. A. (2004). Bangsawan dan kuasa: kembalinya para ningrat di dua kota. Institute for Research and Empowerment.

Fraser, N. (1990). Rethinking the public sphere: A contribution to the critique of actually existing democracy. Social text, (25/26), 56-80.

Habermas, J. (1996). Between facts and norms: Contributions to a discourse theory of law and democracy. Mit Press.

Habermas, J. (2010). Ruang publik: sebuah kajian, tentang kategori, masyarakat borjuis. Balesastra Pustaka.

Hardiman, F. B. (2009). Demokrasi deliberatif: menimbang negara hukum dan ruang publik dalam teori diskursus Jurgen Habermas. Kanisius.

Hardiman, F. B. (2009). Demokrasi deliberatif: menimbang negara hukum dan ruang publik dalam teori diskursus Jurgen Habermas. Kanisius.
Jones, P. (2009). Pengantar teori-teori sosial: dari teori fungsionalisme hingga postmodernisme. Yayasan Obor Indonesia.

Keane, J. (2000). 'Structural Transformation of the Public Sphere' dalam Kenneth L. Hacker dan Jan Van Dick (Eds.). Digital Democracy: Issues of Theory and Practice. London: Sage.

King, D. Y. (1982). „Indonesia's New Order as a Bureaucratic Polity, a Neopatrimonial Regime or a Bureaucratic Authoritarian Regime: What Difference Does It Make?". Interpreting Indonesian politics: Thirteen contributions to the debate, 62, 104-16.

Koentjaraningrat. (1974). Kebudayaan, mentalitet, dan pembangunan: bungarampai. Gramedia.

Kusno, A., Utama, C., \& Nazir, M. (2007). Penjaga memori: gardu di perkotaan Jawa. Ombak.

Lofland, L. H. (1998). The public realm: Exploring the city's quintessential social territory. Transaction Publishers.

McVey, R. (1982). The Beamtenstaat in Indonesia. Interpreting Indonesian politics: Thirteen contributions to the debate, 84-91.

O'G, A. B. (1972). The idea of power in Javanese culture. Culture and Politics in Indonesia, 1-69.

Prasetyo, A. G. (2012). Menuju Demokrasi Rasional: Melacak Pemikiran Jürgen Habermas tentang Ruang Publik. Jurnal Ilmu Sosial dan Ilmu Politik, 16(2), 169-185. 
Putnam, R. D. (2001). Bowling alone: The collapse and revival of American community. Simon and Schuster.

Soemardjan, S. (1991). Perubahan Sosial. Yogyakarta: Gadjah Mada University Press.

Sudibyo, Agus, dkk. (2005). Republik Tanpa Ruang Publik. Yogyakarta: IRE Press.

Sutherland, H., \& Sunarto. (1983). Terbentuknya sebuah elite birokrasi. Sinar Harapan.

Charles Taylor. (2004). Modern social imaginaries. Duke University Press. 